\title{
Article \\ Use of Agri-Food Composts in Almond Organic Production: Effects on Soil and Fruit Quality
}

\author{
María Dolores Pérez-Murcia ${ }^{1}$, María Ángeles Bustamante ${ }^{1, *}{ }^{\mathbb{C}}$, Luciano Orden ${ }^{2}{ }^{\mathbb{D}}$, Rosa Rubio ${ }^{1}$, Enrique Agulló ${ }^{1}$, \\ Ángel A. Carbonell-Barrachina ${ }^{3}$ (1) and Raúl Moral ${ }^{1}$ \\ 1 Department of Agrochemistry and Environment, Miguel Hernández University, EPS-Orihuela, ctra. Beniel \\ km 3.2, 03312 Orihuela, Alicante, Spain; perez.murcia@umh.es (M.D.P.-M.); rosa.rubio@umh.es (R.R.); \\ enrique.agullo@umh.es (E.A.); raul.moral@umh.es (R.M.) \\ 2 Department of Agronomy, Universidad Nacional del Sur. San Andrés 800, \\ Bahía Blanca 8000, Buenos Aires, Argentina; luciano.orden@uns.edu.ar \\ 3 Research Group "Food Quality and Safety", Department of Agro-Food Technology, Miguel Hernández \\ University, ctra. Beniel, km 3.2, 03312 Orihuela, Alicante, Spain; angel.carbonell@umh.es \\ * Correspondence: marian.bustamante@umh.es
}

\section{check for} updates

Citation: Pérez-Murcia, M.D.; Bustamante, M.Á.; Orden, L.; Rubio, R.; Agulló, E.; Carbonell-Barrachina, Á.A.; Moral, R. Use of Agri-Food Composts in Almond Organic Production: Effects on Soil and Fruit Quality. Agronomy 2021, 11, 536. https://doi.org/10.3390/ agronomy11030536

Academic Editor: Francesc Xavier Prenafeta Boldú

Received: 4 February 2021

Accepted: 10 March 2021

Published: 12 March 2021

Publisher's Note: MDPI stays neutral with regard to jurisdictional claims in published maps and institutional affiliations.

Copyright: (c) 2021 by the authors. Licensee MDPI, Basel, Switzerland. This article is an open access article distributed under the terms and conditions of the Creative Commons Attribution (CC BY) license (https:// creativecommons.org/licenses/by/ $4.0 /)$.
Abstract: The objective of this work was to study the agronomic effects of the application of agri-food composts in almond trees (Prunus dulcis L.) cultivated in two different areas with different almond varieties (cv. Guara and cv. Ferraduel), with both in organic farming conditions throughout two cropping cycles. To reach this objective, almond production and quality issues (seed production, kernel yield, nutrient contents and kernel quality), as well as several physico-chemical and biological properties of the amended soils at the beginning and at the end of each campaign were studied. The four composts used (C1, C2, C3 and C4) were elaborated mainly using exhausted grape marc (EGM) and other wastes (waste from orange juice production, OW; waste from tomato soup production, TW; cattle manure, CM; and sheep manure, SM). Two treatments were used as control treatments, one based on sheep manure and another without any amendment. The composts used produced similar results in kernel yield and production compared to the traditional treatment (sheep manure). However, the thickness of the kernel was higher in the treatments using composts with exhausted grape marc and sheep manure or tomato soup waste. In relation to the almond quality, few differences related to the effect of treatments were observed, except for the content of proteins, sucrose, some fatty acids and vegetal sterols.

Keywords: organic farming; compost; fertilization; almond; fruit quality

\section{Introduction}

The extensive management of typically Mediterranean crops such as olives, almonds or grapevines under organic farming conditions (OFC) demands specific sources of organic fertilizers and amendments, which must be validated by specific regulations in an agronomic scenario with a very significant scarcity of traditional manures. Spanish almond production constitutes $84 \%$ of the European production and $5 \%$ of the worldwide production, with around 330,000 tons in 2018 (more than 77,000 Ha under OFC, representing $15 \%$ of the total area) [1]. The almond tree is a fairly rustic crop that easily adapts to multiple edaphoclimatic zones, with almond cropping in OFC being an added value solution for marginal areas and arid conditions. However, organic almonds have enjoyed premium prices compared to conventional ones, and the premium has decreased as organic production has increased [2].

Composting using wastes from agro-industrial activities can be used in OFC, considering the origin and composition requirements set by the legislation [3]. Co-composting strategies based on the combination of agri-food derived wastes, such as exhausted grape marc, waste from citric and horticultural processing, as well as livestock wastes in semiintensive farms, allows for the obtention of balanced composts with added-value properties 
for OFC. In this sense, there is an increasing scientific literature that highlights the high quality of the composts prepared with this type of agri-food waste and particularly with wastes from winery activities $[4,5]$. However, the study of the agronomic behavior of this type of compost in pluriannual field trials and in different management conditions is required. Bustamante et al. [6] observed a mineralization rate in laboratory incubation trials between $11 \%$ and the $20 \%$ of the added carbon using agri-food composts, with this contribution being highly dependent on the stability of the organic matter and on the mineralogical composition of the amended soil. The contribution of compost amendment in these OFC almond systems can include not only a restoration of the soil organic fertility, but also an improvement of the crop quality. Sanchez-Bel et al. [7] reported better results in organic fertilization compared to a mineral equivalent in almond cultivation using the Guara variety.

For this reason, a two-year experiment using two landraces and hydric conditions was developed in order to compare the application of agri-food composts with the traditional management based on sheep manure amendments, studying production and fruit quality parameters, as well as several physical, chemical and biological properties in the amended soils.

\section{Materials and Methods}

\subsection{Experimental Design}

The field experiments were carried out during two consecutive seasons (2008 and 2009) in two different areas in Alicante (Spain) under OFC controlled by the Valencian Organic Farming Committee; one in Pinoso ( $38^{\circ} 23^{\prime} 13.90^{\prime \prime}$ N $1^{\circ} 05^{\prime} 02.74^{\prime \prime}$ W elevation $634 \mathrm{~m}, 3.9 \%$ slope) with Prunus dulcis cv. Guara almond trees and located irrigation, and another one in Fontanars ( $38^{\circ} 44^{\prime} 38.15^{\prime \prime} \mathrm{N}, 0^{\circ} 52^{\prime} 19.36^{\prime \prime} \mathrm{W}$, elevation 605, slope 4.6\%) with Prunus dulcis cv. Ferraduel almond trees, grown in extensive conditions. The climates in these areas are semi-arid for Pinoso (Köppen BSk) and Mediterranean for the Fontanars area (Köppen: Csa). The climatic data at the experimental sites over the study period showed a cumulative rainfall of 314 and $388 \mathrm{~mm}$ and a mean temperature of $15.1^{\circ} \mathrm{C}$ and $14.7^{\circ} \mathrm{C}$ for the field areas of Pinoso and Fontanars, respectively. The temperature and rainfall patterns observed in the years corresponding to the study were typical of the areas studied. Weather data were obtained from two meteorological stations belonging to the IVIA-GVA (Valencian Community) located at the experimental sites. Soils in both areas were calcareous, sandy loam textured, with an alkaline $\mathrm{pH}$ and low fertility (Table 1).

Table 1. Main soil properties of $0-30 \mathrm{~cm}$ soil layer at the experimental sites.

\begin{tabular}{|c|c|c|}
\hline Parameter & Soil 1 & Soil 2 \\
\hline $\mathrm{pH}$ & $8.82 \pm 0.01$ & $8.56 \pm 0.01$ \\
\hline $\mathrm{EC}\left(\mathrm{dS} \mathrm{m}^{-1}\right)$ & $0.11 \pm 0.00$ & $0.21 \pm 0.01$ \\
\hline Total carbonate equivalent (\%) & $62.5 \pm 0.5$ & $22.8 \pm 0.1$ \\
\hline \multicolumn{3}{|l|}{ Soil texture } \\
\hline Thick elements (\%) & $13.2 \pm 0.1$ & $32.6 \pm 0.1$ \\
\hline Sand $(\%)$ & $75.3 \pm 0.1$ & $70.5 \pm 0.0$ \\
\hline Silt $(\%)$ & $16.6 \pm 0.1$ & $15.5 \pm 0.1$ \\
\hline Clay $(\%)$ & $8.2 \pm 0.1$ & $14.0 \pm 0.1$ \\
\hline Oxidizable organic $C\left(\mathrm{~g} \mathrm{~kg}^{-1}\right)$ & $5.10 \pm 0.03$ & $5.22 \pm 0.37$ \\
\hline Total Kjeldahl N $\left(\mathrm{g} \mathrm{kg}^{-1}\right)$ & $0.70 \pm 0.00$ & $0.70 \pm 0.00$ \\
\hline $\mathrm{NO}_{3}{ }^{-}-\mathrm{N}\left(\mathrm{mg} \mathrm{kg}^{-1}\right)$ & $17.3 \pm 0.0$ & $21.8 \pm 0.8$ \\
\hline
\end{tabular}

Soil 1: soil from the experimental site located in Pinoso; Soil 2: soil from the experimental site located in Fontanars. EC: electrical conductivity. Data values are reported as mean value $(n=3) \pm$ standard error.

Four different organic amendments based on agri-food compost were applied as a single application at the beginning of the experiment in each experimental area (Pinoso and Fontanars) using two reference treatments to confirm the efficiency and the agronomic behavior of these composts-one based on sheep manure with ferrous sulphate as an 
additive, the amendment traditionally employed in trial areas, and a control treatment, in which no organic amendment was used. The amendment application rate complied in all cases with Ecologic Agriculture regulations for manures [3], which allow $170 \mathrm{~kg} \mathrm{~N} \mathrm{ha}^{-1}$. Each treatment was applied once in four subplots covering 15 trees each, with a row spacing of $7 \times 7 \mathrm{~m}^{2}$ (row $\times$ almond tree), equivalent to 205 almond tree ha ${ }^{-1}$. Treated and non-treated plots were arranged in a completely randomized block design. The border effect was eliminated by guard rows at the edge of each block.

In Table 2 the main characteristics of the organic materials used are shown. The composts used were prepared mainly using exhausted grape marc (EGM) from a distillery, mixed with other residual materials (orange juice waste, OW; tomato soup waste, TW; sheep manure, SM; cattle manure, $\mathrm{CM}$ ), with all these wastes having origin and composition requirements within those established by the legislation to be fit for their use in organic farming [3]. The proportions of these components in the composting mixtures were as follows (on a dry-weight basis):

- $\quad$ C1: $60 \% \mathrm{EGM}+40 \%$ OW

- $\quad$ C2: $60 \% \mathrm{EGM}+40 \% \mathrm{TW}$

- $\quad$ C3: $60 \% \mathrm{EGM}+40 \% \mathrm{CM}$

- $\mathrm{C} 4: 60 \% \mathrm{EGM}+40 \% \mathrm{SM}$

Table 2. Characteristics of the organic materials used in the experiment.

\begin{tabular}{lccccc}
\hline & C1 & C2 & C3 & C4 & Sheep Manure \\
\hline pH & $7.28 \pm 0.01$ & $7.25 \pm 0.06$ & $7.88 \pm 0.02$ & $7.61 \pm 0.03$ & $7.46 \pm 0.02$ \\
$\mathrm{EC}\left(\mathrm{dS} \mathrm{m}^{-1}\right)$ & $2.75 \pm 0.06$ & $2.62 \pm 0.01$ & $6.15 \pm 0.12$ & $5.64 \pm 0.04$ & $6.99 \pm 0.10$ \\
$\mathrm{TOM}(\%)$ & $83.4 \pm 1.65$ & $86.2 \pm 0.74$ & $74.2 \pm 0.06$ & $61.3 \pm 0.78$ & $34.9 \pm 0.21$ \\
$\mathrm{TOC}(\%)$ & $47.5 \pm 0.49$ & $49.5 \pm 0.21$ & $42.2 \pm 1.63$ & $33.9 \pm 0.71$ & $17.9 \pm 0.18$ \\
$\mathrm{TN}(\%)$ & $2.86 \pm 0.13$ & $2.95 \pm 0.02$ & $2.92 \pm 0.13$ & $2.34 \pm 0.05$ & $1.73 \pm 0.01$ \\
$\mathrm{C}: \mathrm{N} \mathrm{ratio}$ & $16.6 \pm 0.76$ & $16.8 \pm 0.04$ & $14.5 \pm 0.08$ & $14.5 \pm 0.59$ & $10.3 \pm 0.11$ \\
$\mathrm{P}\left(\mathrm{g} \mathrm{kg}^{-1}\right)$ & $3.09 \pm 0.42$ & $4.85 \pm 0.13$ & $6.46 \pm 0.20$ & $5.12 \pm 0.28$ & $2.53 \pm 0.31$ \\
$\mathrm{Ca}\left(\mathrm{g} \mathrm{kg}^{-1}\right)$ & $26.4 \pm 1.2$ & $21.0 \pm 3.8$ & $34.5 \pm 1.1$ & $72.4 \pm 0.8$ & $64.3 \pm 1.5$ \\
$\mathrm{Mg}\left(\mathrm{g} \mathrm{kg}^{-1}\right)$ & $1.97 \pm 0.11$ & $1.89 \pm 0.12$ & $5.91 \pm 0.40$ & $5.84 \pm 0.51$ & $4.79 \pm 0.40$ \\
$\mathrm{~K}\left(\mathrm{~g} \mathrm{~kg}^{-1}\right)$ & $10.2 \pm 1.1$ & $14.0 \pm 0.5$ & $18.6 \pm 0.2$ & $15.3 \pm 1.5$ & $8.11 \pm 0.15$ \\
$\mathrm{Na}\left(\mathrm{mg} \mathrm{kg}^{-1}\right)$ & $641 \pm 2$ & $537 \pm 6$ & $6712 \pm 121$ & $3678 \pm 24$ & $1380 \pm 33$ \\
$\mathrm{Fe}\left(\mathrm{mg} \mathrm{kg}^{-1}\right)$ & $717 \pm 43$ & $746 \pm 55$ & $1907 \pm 2$ & $3704 \pm 77$ & $7000 \pm 81$ \\
$\mathrm{Cu}\left(\mathrm{mg} \mathrm{kg}^{-1}\right)$ & $14.0 \pm 0.2$ & $16.1 \pm 0.6$ & $25.1 \pm 0.6$ & $16.7 \pm 2.5$ & $7.60 \pm 0.12$ \\
$\mathrm{Mn}\left(\mathrm{mg} \mathrm{kg}^{-1}\right)$ & $23.3 \pm 2.0$ & $31.0 \pm 1.4$ & $98.7 \pm 1.4$ & $114 \pm 6$ & $135 \pm 3$ \\
$\mathrm{Zn}\left(\mathrm{mg} \mathrm{kg}^{-1}\right)$ & $274 \pm 1$ & $179 \pm 3$ & $137 \pm 4$ & $93 \pm 7$ & $50 \pm 6$
\end{tabular}

C1: 60\% EGM + 40\% OW; C2: 60\% EGM + 40\% TW; C3: 60\% EGM + 40\% CM; C4: 60\% EGM + 40\% SM. EGM: exhausted grape marc; $\mathrm{OW}$ : orange juice waste; TW: tomato soup waste; $\mathrm{CM}$ : cattle manure; SM: sheep manure. EC: electrical conductivity; TOM: total organic matter; TOC: total organic carbon; TN: total nitrogen. Data values are reported as mean value $(n=3) \pm$ standard error.

These composts showed similar $\mathrm{pH}$ values, between 7.25 and 7.88. The electrical conductivity was moderate ( $\mathrm{EC}<3 \mathrm{dS} \mathrm{m}^{-1}$ ); except in sheep manure and in composts $\mathrm{C} 3$ and $\mathrm{C} 4$, for which the electrical conductivity values were higher, possibly (in the case of the composts) due to the use of manures in their elaboration [8]. The $\mathrm{N}$ content exceeded $2 \%$ in all composts. On the other hand, the $\mathrm{C} / \mathrm{N}$ ratio showed suitable values according to reference values [9], indicating a good degree of maturity. The use of cattle manure increased the phosphorus content in composts. Composts $\mathrm{C} 3$ and $\mathrm{C} 4$ also showed higher potassium content than the rest of the organic materials, as well as higher sodium content due to the incorporation of mineral salts in the diet of ruminant cattle. The micronutrient contents were adequate, and in the case of $\mathrm{Cu}$ and $\mathrm{Zn}$, fulfilled the Spanish legislation [10].

\subsection{Analytical and Statistical Methods}

Both the determinations made in the soil and the organic amendments were analyzed according to the methods used by Bustamante et al. $[6,9,11]$. In the case of vegetable matter, almond production, seed yield and kernel dimensions (length, width and thickness) were 
studied. Kernel macronutrients ( $\mathrm{P}, \mathrm{K}, \mathrm{Ca}$ and $\mathrm{Mg}$ ) and kernel micronutrients $(\mathrm{Fe}, \mathrm{Cu}$, $\mathrm{Mn}$ and $\mathrm{Zn}$ ) were detected in the nitric-perchloric digestion extract through Inductively Coupled Plasma-Mass Spectrometry (ICP-MS). C and N content was determined in a C/N macro elemental analyzer, whereas $\mathrm{P}$ content was determined colorimetrically [12]. Finally, different kernel quality parameters (humidity, fiber, proteins, fat, sucrose, global sucrose, palmitic C16, stearic C 18, oleic C 18 1, linoleic C18 2, cholesterol, campesterol, estigmasterol, $\beta$-sitosterol and total sterols) were determined by Near-Infrared Spectroscopy NIRS analysis using the equipment and calibrations from the Regulatory Council of Appellation of Origin Turron de Jijona.

In order to assess the overall effects of the organic amendments on soil characteristics and almond quality and production, different statistical analyses were conducted. The model used for analysis of variance of the data concerning soil parameters was the two-way repeated measures ANOVA test, considering the type of treatment and time. In the case of almond yield and production parameters and nutrient contents of kernels, the mean average values of each parameter considering both crops and areas were tested using one-way analysis of variance (ANOVA). The general linear model (GLM) was used to study the effects of the factors studied (fertilizing treatment, crop variety and type of area) on the morphological quality, organoleptic and nutritional quality of the kernel. In all cases, the Tukey- $b$ post-hoc test was used to evaluate the differences between specific averages $(p<0.05)$. Data analysis was carried out using the SPSS v. 18.0 statistical software package.

\section{Results and Discussion}

\subsection{Effect of the Treatments on Soil Properties}

Different effects were observed regarding the edaphic properties, depending on the degree of stability of the amendments and, to a lesser extent, on the typology of the composts used (Table 3). The use of the organic treatments did not imply a significant variation in soil $\mathrm{pH}$, except for manure, which produced a slight acidification, together with $\mathrm{C} 1$ compost, probably due to the limestone nature of these soils, which involves a buffer effect that avoids sudden changes in the $\mathrm{pH}$ with the addition of organic matter [13]. All amendments produced a significant increase in conductivity due to the incorporation of water-soluble salts, with manure standing out, with initial growth rates of up to five times, decreasing over time in all cases, although maintaining values that almost doubled those in the control treatments. In addition, soil organic amendments caused sustained increases in oxidizable organic-carbon content (from 2 to $3 \mathrm{~g} \mathrm{C} \mathrm{kg} \mathrm{soil}{ }^{-1}$ ) and nitrogen associated with organic matter compared to the control.

The content of nitrates in the soil was also significantly increased, especially in manure, with this effect being sustained over time, possibly due to the faster mineralization of the organic matter present in this waste, being a non-stabilized material [11]. The P fraction available was higher in all the fertilized scenarios after the application compared to the unfertilized controls, with this effect being importantly attenuated over time, probably due to the extraction and reduction of bioavailability as a result of the nature of limestone and soil $\mathrm{pH}$. All amendments proved to be excellent available K sources, as their levels increased at least two-fold compared to the control, and this increase was also significant for manure. Although the development of the experiment seemed to show a general decrease in the content of this macroelement, the fertilizing effect at a potassium level should be highlighted. This nutrient is usually considered very movable in the cultivable layer but it maintained significantly higher average values in the soil than the controls in both areas, which was probably associated with the design of balanced composts with waste derived from specific plant parts (fruit) that are naturally rich in K. However, the sodification effect of the amendments was low compared to the control, when compared to the potassium increase, although it was maintained at least until the end of the second crop cycle.

As shown in Table 3, the amendments affected soil biotic activity. Regarding microbial biomass $\mathrm{C}$ level and edaphic respiration, we also observed initially that amendments generated generalized and significant increases in these parameters with respect to the 
control, as other authors observed when adding organic amendments to the soil $[6,14,15]$. Manure was not the most efficient treatment when activating the soil, since although it provided the maximum relative initial water-soluble $\mathrm{C}$, it did not generate the highest levels of microbial biomass. Sustained effects are important, although the different composts seemed to behave similarly, perhaps highlighting $\mathrm{C} 3$ and $\mathrm{C} 4$ composts, in terms of biomass $\mathrm{C}$ and water-soluble $\mathrm{C}$ values, as the most balanced composts, considering their effect on soil biotic activity. In any case, the capacity of the composts to provide a good and lasting source of nutrients for crop and soil biological activity is, in view of the data obtained, highlighted.

Table 3. Average values of soil parameters during the experiment according to the treatment used, considering both areas.

\begin{tabular}{|c|c|c|c|c|c|c|}
\hline Treatment & $\mathrm{pH}$ & $\begin{array}{c}\mathrm{EC} \\
\left(\mathrm{dS} \mathrm{m}^{-1}\right)\end{array}$ & $\begin{array}{c}\mathrm{OC} \\
\left(\mathrm{g} \mathrm{kg}^{-1}\right)\end{array}$ & $\begin{array}{c}\text { TKN } \\
\left(\mathrm{g} \mathrm{kg}^{-1}\right)\end{array}$ & $\begin{array}{l}\mathrm{N}-\mathrm{NO}_{3}^{-} \\
\left(\mathrm{g} \mathrm{kg}^{-1}\right)\end{array}$ & $\begin{array}{c}P \\
\left(\mathrm{mg} \mathrm{kg}^{-1}\right)\end{array}$ \\
\hline Control & $8.60 c$ & $0.11 \mathrm{a}$ & $5.96 a$ & $0.80 \mathrm{a}$ & $27 a$ & $28 a$ \\
\hline $\begin{array}{l}\text { Sheep } \\
\text { manure }\end{array}$ & $8.33 a$ & $0.36 \mathrm{e}$ & $8.24 b$ & $1.17 \mathrm{~b}$ & $81 d$ & $39 \mathrm{c}$ \\
\hline $\mathrm{C} 1$ & $8.40 \mathrm{~b}$ & $0.20 \mathrm{c}$ & $11.3 \mathrm{c}$ & $1.69 \mathrm{~d}$ & $32 b$ & $45 d$ \\
\hline $\mathrm{C} 2$ & $8.61 c$ & $0.17 \mathrm{~b}$ & $8.13 b$ & $1.32 \mathrm{c}$ & $37 \mathrm{c}$ & $33 b$ \\
\hline C3 & $8.64 c$ & $0.24 \mathrm{~d}$ & $7.79 b$ & $1.22 \mathrm{~b}$ & $37 c$ & $46 \mathrm{~d}$ \\
\hline $\mathrm{C} 4$ & $8.65 c$ & $0.24 \mathrm{~d}$ & $7.81 b$ & $1.31 \mathrm{c}$ & $29 \mathrm{ab}$ & $43 d$ \\
\hline F-ANOVA & $122 * * *$ & $256^{* * *}$ & $71^{* * *}$ & $87^{* * *}$ & $447^{* * *}$ & $114^{* * *}$ \\
\hline Treatment & $\underset{\left(\mathrm{g} \mathrm{kg}^{-1}\right)}{\mathrm{K}}$ & $\begin{array}{c}\mathrm{Na} \\
\left(\mathrm{g} \mathrm{kg}^{-1}\right)\end{array}$ & $\begin{array}{c}\mathrm{MBC} \\
\left(\mathrm{mg} \mathrm{kg}^{-1}\right)\end{array}$ & $\begin{array}{c}\text { Soil Respiration } \\
\left(\mathrm{mg} \mathrm{CO}_{2} \mathrm{~kg}^{-1} \text { day }^{-1}\right)\end{array}$ & $\begin{array}{c}\text { WSC } \\
\left(\mathrm{mg} \mathrm{kg}^{-1}\right)\end{array}$ & $\begin{array}{c}\mathrm{qCO}_{2} \\
\left(\mathrm{mg} \mathrm{C}-\mathrm{CO}_{2} \mathrm{~g}^{-1} \mathrm{MBC} \mathrm{day}^{-1}\right)\end{array}$ \\
\hline Control & $0.19 a$ & $0.53 a$ & $121 a$ & $113 a$ & $117 a$ & $263 b c$ \\
\hline $\begin{array}{l}\text { Sheep } \\
\text { manure }\end{array}$ & $0.51 b$ & $0.61 b$ & $197 b$ & $133 b$ & $189 \mathrm{c}$ & $252 b$ \\
\hline C1 & $0.87 \mathrm{e}$ & $0.51 \mathrm{a}$ & $275 d$ & $175 \mathrm{~d}$ & $105 a$ & $296 d$ \\
\hline $\mathrm{C} 2$ & $0.51 b$ & $0.54 \mathrm{a}$ & $210 \mathrm{~b}$ & $148 \mathrm{c}$ & $161 b$ & $255 b$ \\
\hline C3 & $0.58 c$ & $0.65 b$ & $248 \mathrm{c}$ & $129 \mathrm{~b}$ & $176 b c$ & $176 a$ \\
\hline $\mathrm{C} 4$ & $0.66 \mathrm{~d}$ & $0.63 b$ & $242 c$ & $145 c$ & $173 b c$ & $282 \mathrm{~cd}$ \\
\hline F-ANOVA & $194^{* * *}$ & $20^{* * *}$ & $78^{* * *}$ & $84^{* * *}$ & $30^{* * *}$ & $48^{* * *}$ \\
\hline
\end{tabular}

C1: 60\% EGM + 40\% OW; C2: 60\% EGM + 40\% TW; C3: 60\% EGM + 40\% CM; C4: 60\% EGM + 40\% SM. EGM: exhausted wine grape marc; OW: orange juice waste; TW: tomato soup waste; CM: cattle manure; SM: sheep manure. EC: electrical conductivity; OC: oxidizable organic carbon; TKN: Total Kjeldahl nitrogen; MBC: microbial biomass carbon; WSC: water-soluble carbon; $\mathrm{qCO}_{2}:$ metabolic quotient or specific respiration rate. Linear mutivariate analysis of repeated measures (time-series). Signification: ns: not significant; ${ }^{* * *}: p<0.001$. Average values in a column followed by the same letter are not significantly different at $p<0.05$ (Tukey- $b$ test).

\subsection{Effect of Treatments on Almond Yield}

In the experimental design presented, two types of areas were considered because of their variety and their different agronomic management practices, in order to be able to extrapolate general effects associated with the fertilizing treatments. However, despite this, it is difficult to conclude that amendments improved production with regard to unfertilized control treatments (Table 4), showing in this case that organically managed soils presented a quite significant damping effect. This fact was as well observed by Valverde et al. [16] in an almond crop experiment in different water regimes and types of fertilization. The lack of a conventional control managed inorganically failed to allow the comparison of both types of management. In any case, it appears that the composts $\mathrm{C} 2$ to $\mathrm{C} 4$ showed comparable effects to manure regarding crop and yield, with these effects being nonsignificant compared to the control treatment. On the contrary, the compost made from exhausted grape marc and orange juice waste (C1) led to lower yield and production levels, probably due to this compost inducing the maximum values of nitrogen and potassium in the soil. Different studied have reported the importance of nitrogen and potassium for almond crops, since these macronutrients are required in large amounts by this crop. Thus, Muhammad et al. [17] found a decrease in the individual fruit weight and yield with increasing $\mathrm{N}$ application, an effect observed by other authors in other tree species, such as pistachio [18] and apple [19]. Concerning the effect of potassium, different studies [20,21] 
have reported no significant influence of $\mathrm{K}$ fertilizers on almond fruit weight and yields, although the studies have also shown that this effect could be site-specific.

Table 4. Yield and production average values considering both areas and crops.

\begin{tabular}{lcccc}
\hline Treatment & $\begin{array}{c}\text { Weight Almond } \\
\text { (kg Tree }\end{array}$ & $\begin{array}{c}\text { Weight Kernel } \\
\left(\mathbf{k g ~ T r e e}^{-\mathbf{1}}\right.\end{array}$ & $\begin{array}{c}\text { Yield } \\
\mathbf{( \% )}\end{array}$ & $\begin{array}{c}\text { Average Weight Kernel } \\
\text { (g) }\end{array}$ \\
\hline Control & $5.6 \mathrm{ab}$ & $1.6 \mathrm{ab}$ & $25.1 \mathrm{ab}$ & $1.74 \mathrm{ab}$ \\
Manure & $6.1 \mathrm{ab}$ & $1.8 \mathrm{ab}$ & $25.8 \mathrm{ab}$ & $1.81 \mathrm{ab}$ \\
C1 & $2.8 \mathrm{a}$ & $0.6 \mathrm{a}$ & $22.0 \mathrm{a}$ & $1.50 \mathrm{a}$ \\
C2 & $6.2 \mathrm{ab}$ & $1.9 \mathrm{ab}$ & $26.1 \mathrm{~b}$ & $1.99 \mathrm{~b}$ \\
C3 & $7.5 \mathrm{~b}$ & $2.2 \mathrm{~b}$ & $25.8 \mathrm{ab}$ & $1.94 \mathrm{~b}$ \\
C4 & $5.6 \mathrm{ab}$ & $1.6 \mathrm{ab}$ & $26.1 \mathrm{~b}$ & $1.68 \mathrm{ab}$ \\
F-ANOVA & $11.8^{* * *}$ & $3.3^{*}$ & $2.8^{*}$ & $4.1^{*}$ \\
\hline
\end{tabular}

${ }^{1}$ Relationship between kernel weight and full almond. C1: 60\% EGM + 40\% OW; C2: 60\% EGM + 40\% TW; C3: 60\% EGM + 40\% CM; C4: $60 \%$ EGM + 40\% SM. EGM: exhausted wine grape marc; OW: orange juice waste; TW: tomato soup waste; CM: cattle manure; SM: sheep manure. Signification: ns: not significant; *: $p<0.05 ;{ }^{* * *}: p<0.001$. Average values in a column followed by the same letter are not significantly different at $p<0.05$ (Tukey-b test).

\subsection{Effect of Treatments on the Quality and Nutrient Contents in the Fruit}

Table 5 shows the statistical analysis of the morphological qualities of the kernels, in which a wide variability associated with the treatments (amendments, crop, area-varietymanagement) was observed, and this seemed to have an influence in a significant and complex way on the different scenarios, in relation to length, width and thickness. Valverde et al. [16] observed that the almond's physical properties (thickness, length, mass and width) depended fundamentally on the type of crop system. However, concerning the effect of the treatments regarding thickness as a quality parameter, compost $\mathrm{C} 4$ was the only treatment that significantly enhanced this parameter compared with the control treatment, with the rest of fertilizing treatments having a similar effect on thickness to the treatment without fertilization, except for compost C1 (Figure 1). Once again, compost C1 did not improve kernel productive parameters, demonstrating the importance of the validation of each compost specifically in field conditions, since improvements in the soil environment do not always imply the best yields.

Table 5. Multivariate statistical analysis regarding the morphological qualities of the kernels.

\begin{tabular}{|c|c|c|c|}
\hline Variable & $\begin{array}{c}\text { Length } \\
\text { F-ANOVA }\end{array}$ & $\begin{array}{c}\text { Width } \\
\text { F-ANOVA }\end{array}$ & $\begin{array}{l}\text { Thickness } \\
\text { F-ANOVA }\end{array}$ \\
\hline Fertilizing treatment & $0.602 \mathrm{~ns}$ & $1.807 \mathrm{~ns}$ & $3.714^{* *}$ \\
\hline Crop & $2.683 \mathrm{~ns}$ & $14.747^{* * *}$ & $405.409^{* * *}$ \\
\hline Farm (area-variety) & $136.956 c$ & $376.819^{* * *}$ & $65.785^{* * *}$ \\
\hline Treatment $\times$ Crop & $2.349 *$ & $1.377 \mathrm{~ns}$ & 1.146ns \\
\hline Treatment $\times$ Farm & $3.660 * *$ & $4.100^{* *}$ & $0.980 \mathrm{~ns}$ \\
\hline Crop $\times$ Farm & $127.535^{* * *}$ & $7.523^{* *}$ & $0.825 \mathrm{~ns}$ \\
\hline Treatment $\times$ Crop $\times$ Farm & 1.038ns & $1.796 \mathrm{~ns}$ & $1.539 \mathrm{~ns}$ \\
\hline
\end{tabular}

Signification: ns: not significant; ${ }^{*}: p<0.05 ;{ }^{* *}: p<0.01 ;{ }^{* * *}: p<0.001$.

Table 6 shows the incidence of the design variables (treatment, crop, plot) with respect to composition and nutritional parameters estimated using the NIRS technique in almond kernels. As can be seen, most of the estimated parameters depended more on agronomic aspects such as crop and plot (which includes both almond variety and crop management) than on the fertilizing treatments. However, Sanchez-Bel et al. [7] observed, in the Guara almond variety, a higher content of sugars and organic acids and a better quality of oil in irrigated conditions. In addition, the organic treatments produced almonds with a higher content of sugar, organic acids and fiber and a similar fat content. Askin et al. [22] reported that the content of certain fatty acids, such as palmitic, estearic, oleic and linoleic acids was influenced by the weight of the almond (without shell) and by the thickness of the shell; 
therefore, the almond variety could be the factor with the highest influence with respect to the content of fatty acids. Nevertheless, the protein content, as a reflection of the content of provided nitrogen, as well as sucrose and some organic acids and sterols are affected by the existence of organic contributions and their typology. This is a fairly interesting field in ecological agriculture, since most of the added value can be based on this type of properties, determining, for example, the harvesting of other crops of interest such as the olive.

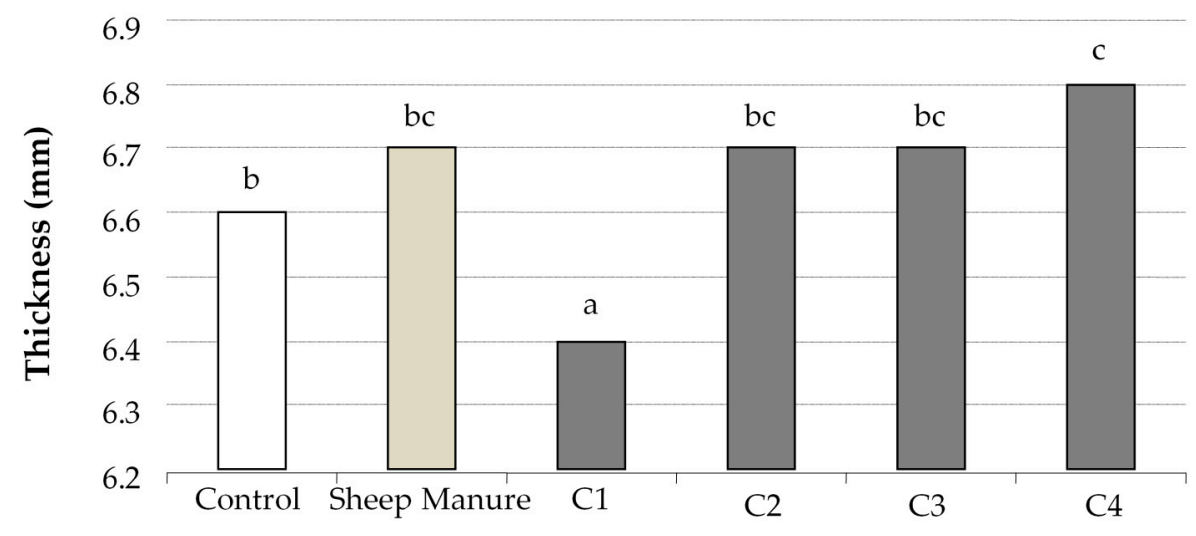

Figure 1. Effects of the treatments on the thickness of the kernel, independently of the species and plot analyzed. Mean values of each treatment followed by the same letter are not significantly different at $p<0.05$ (Tukey- $b$ test).

Table 6. Multivariate statistical analysis regarding organoleptic and nutritional quality of the kernels.

\begin{tabular}{cccc}
\hline Parameter & $\begin{array}{c}\text { Amendment } \\
\text { F-ANOVA }\end{array}$ & $\begin{array}{c}\text { Crop } \\
\text { F-ANOVA }\end{array}$ & $\begin{array}{c}\text { Plot } \\
\text { F-ANOVA }\end{array}$ \\
\hline Humidity & $1.53 \mathrm{~ns}$ & $636^{* * *}$ & $18.0^{* * *}$ \\
Fiber & $1.69 \mathrm{~ns}$ & $0.47 \mathrm{~ns}$ & $567^{* * *}$ \\
Proteins & $2.53^{*}$ & $0.48 \mathrm{~ns}$ & $39^{* * *}$ \\
Fat & $0.87 \mathrm{~ns}$ & $26.6^{* * *}$ & $194^{* * *}$ \\
Sucrose & $1.34 \mathrm{~ns}$ & $135^{* * *}$ & $173^{* * *}$ \\
Global Sucrose & $3.18^{*}$ & $176^{* * *}$ & $11.8^{* *}$ \\
C 16 Palmitic & $0.84 \mathrm{~ns}$ & $321^{* * *}$ & $37.7^{* * *}$ \\
C 18 Estearic & $1.78 \mathrm{~ns}$ & $46^{* * *}$ & $21.9^{* * *}$ \\
C 18 1 Oleic & $1.97 \mathrm{~ns}$ & $1.31 \mathrm{~ns}$ & $2.14 \mathrm{~ns}$ \\
C 18 2 Linoleic & $2.33^{*}$ & $6.25^{*}$ & $8.51^{* *}$ \\
Cholesterol & $1.60 \mathrm{~ns}$ & $0.499 \mathrm{~ns}$ & $14.5^{* * *}$ \\
Campesterol & $1.66 \mathrm{~ns}$ & $1.23 \mathrm{~ns}$ & $6.27 \mathrm{~ns}$ \\
Estigmasterol & $2.74^{*}$ & $1256^{* * *}$ & $22.1^{* * *}$ \\
B-Sitosterol & $0.45 \mathrm{~ns}$ & $59^{* * *}$ & $1.59 \mathrm{~ns}$ \\
Total sterols & $1.42 \mathrm{~ns}$ & $10.5^{* *}$ & $10.4^{* * *}$ \\
\hline
\end{tabular}

Signification: ns: not significant; *: $p<0.05 ; * *: p<0.01 ;{ }^{* * *}: p<0.001$.

Table 7 shows the statistical analysis obtained for the organic treatment variable, considering both areas together, with a different type of almond tree variety, as well as management (irrigated and unirrigated) for both crops. It seems clear that the application of the tested organic matter sources did not encourage sustainable changes in the concentrations of $\mathrm{C}$ and $\mathrm{N}$ in kernels. However, it should be highlighted that phosphorus increased in those with organic fertilization. This fact has been stated as a usual effect in organic management [14]. These contents are probably a demonstration of the increase in available $P$ in the soil, both because of exogenous contributions and because of an improvement in its bioavailability, depending on the forms of $\mathrm{P}$ in these composts. Manure is poor in $\mathrm{K}$, regarding the unfertilized control, whereas most of the composts, except for compost C2, sustainably improved the $\mathrm{K}$ content in kernels. It is also remarkable that the content of 
secondary macronutrients, such as $\mathrm{Ca}$ and $\mathrm{Mg}$, in kernels were not affected by treatments compared to the control, probably due to the high basal contents in these soils. Fe contents in kernels were not sustainably affected, whereas other micronutrients such as $\mathrm{Cu}, \mathrm{Mn}$ and Zn were higher compared to control treatments, with no substantial differences between the different composts and manure. Regarding sodium concentration, the addition of amendments did not generate an $\mathrm{Na}$ increase in kernels in spite of its higher concentrations in the soil (data not shown).

Table 7. Nutrient content average values in kernels, considering both areas and crops.

\begin{tabular}{|c|c|c|c|c|c|c|c|c|c|c|}
\hline & $\begin{array}{c}\mathrm{C} \\
\left(\mathrm{g} \mathrm{kg}^{-1}\right)\end{array}$ & $\begin{array}{c}\mathrm{N} \\
\left(\mathrm{g} \mathrm{kg}^{-1}\right)\end{array}$ & $\begin{array}{c}P \\
\left(g^{k g} g^{-1}\right)\end{array}$ & $\begin{array}{c}\mathrm{K} \\
\left(\mathrm{g} \mathrm{kg}^{-1}\right)\end{array}$ & $\begin{array}{c}\text { Ca } \\
\left(\mathrm{g} \mathrm{kg}^{-1}\right)\end{array}$ & $\begin{array}{c}\mathrm{Mg} \\
\left(\mathrm{g} \mathrm{kg}^{-1}\right)\end{array}$ & $\begin{array}{c}\mathrm{Fe} \\
\left(\mathrm{mg} \mathrm{kg}^{-1}\right)\end{array}$ & $\begin{array}{c}\mathrm{Cu} \\
\left(\mathrm{mg} \mathrm{kg}^{-1}\right)\end{array}$ & $\begin{array}{c}\mathrm{Mn} \\
\left(\mathrm{mg} \mathrm{kg}^{-1}\right)\end{array}$ & $\begin{array}{c}\mathrm{Zn} \\
\left(\mathrm{mg} \mathrm{kg}^{-1}\right)\end{array}$ \\
\hline Control & $642 a$ & $40 a$ & $5.23 a$ & $7.33 a$ & $3.4 \mathrm{~b}$ & $2.25 \mathrm{a}$ & $37 a b$ & $13.7 \mathrm{a}$ & $13.1 \mathrm{a}$ & $48 a$ \\
\hline Manure & $641 a$ & $39 a$ & $5.44 \mathrm{~b}$ & $7.28 \mathrm{a}$ & 3.3ab & $2.26 \mathrm{a}$ & $36 a$ & $14.5 \mathrm{ab}$ & $14.3 \mathrm{~b}$ & $51 \mathrm{ab}$ \\
\hline $\mathrm{C} 1$ & $636 a$ & $44 a$ & $6.21 \mathrm{c}$ & $8.32 b$ & $3.1 \mathrm{a}$ & $2.33 a$ & $40 \mathrm{~b}$ & $19.3 \mathrm{c}$ & 13.9ab & $54 \mathrm{~b}$ \\
\hline $\mathrm{C} 2$ & $643 a$ & $40 a$ & $5.44 b$ & $7.45 a$ & $3.5 b$ & $2.33 a$ & $37 a b$ & $16.2 b$ & $14.8 \mathrm{~b}$ & $51 \mathrm{ab}$ \\
\hline C3 & $639 a$ & $39 a$ & $5.35 \mathrm{ab}$ & $7.54 \mathrm{~b}$ & $3.5 b$ & $2.35 \mathrm{a}$ & $35 a$ & $15.0 \mathrm{ab}$ & $14.7 \mathrm{~b}$ & $53 b$ \\
\hline C4 & $637 a$ & $40 a$ & $5.47 \mathrm{~b}$ & $7.54 b$ & $3.5 b$ & $2.37 \mathrm{a}$ & $36 a$ & $14.9 \mathrm{ab}$ & $14.3 \mathrm{~b}$ & $53 b$ \\
\hline $\begin{array}{l}F- \\
A N O V A\end{array}$ & $1.2 \mathrm{~ns}$ & $0.48 \mathrm{~ns}$ & $3.43^{* *}$ & $3.30 * *$ & $2.20 \mathrm{~ns}$ & $2.69 *$ & $5.6^{* * *}$ & $0.50 \mathrm{~ns}$ & $1.76 \mathrm{~ns}$ & $5.2^{* * *}$ \\
\hline
\end{tabular}

Signification: ns: not significant; ${ }^{*}: p<0.05{ }^{* *}: p<0.01 ;^{* * *}: p<0.001$. Average values in a column followed by the same letter are not significantly different at $p<0.05$ (Tukey- $b$ test).

\section{Conclusions}

The results obtained from the application of agri-food composts in two almond production areas under organic farming management during two crop seasons have shown that these composts improved the soil characteristics in both areas, increasing the nutrient content and enhancing the biotic activity, with lower increases in soil salinity and nitrate content than the traditional treatment based on sheep manure. In addition, all the composts, except $\mathrm{C} 1$ (constituted by exhausted grape marc and orange juice waste), showed similar fruit yields and production average values to those of the traditional treatment (sheep manure). Moreover, the organic treatments produced almonds with a higher content of sugars, organic acids and fiber and a similar fat content, indicating additional positive effects of organic management agricultural practices on the organoleptic characteristics of almonds.

Author Contributions: Conceptualization. R.M., M.Á.B. and M.D.P.-M.; methodology. M.D.P.-M., R.R., M.Á.B., E.A. and Á.A.C.-B.; software. R.M., L.O., E.A. and Á.A.C.-B.; validation. R.M., M.Á.B. and M.D.P.-M.; formal analysis. E.A., M.Á.B., R.R. and Á.A.C.-B.; investigation. M.D.P.-M., M.Á.B. and R.M.; resources. R.M., M.D.P.-M. and Á.A.C.-B.; data curation. R.M., M.Á.B., L.O. and Á.A.C.-B.; writing-original draft preparation. M.D.P.-M., R.R., R.M. and M.Á.B.; writing-review and editing. M.Á.B., L.O. and Á.A.C.-B.; visualization. R.M., M.Á.B. and M.D.P.-M.; supervision. R.M., M.Á.B. and M.D.P.-M.; project administration. R.M.; funding acquisition. R.M. All authors have read and agreed to the published version of the manuscript.

Funding: This work has been financed by the Spanish Ministry of Education and Science in the framework of the CICYT CTM2006-01363/TECNO Project.

Institutional Review Board Statement: Not applicable.

Informed Consent Statement: Not applicable.

Data Availability Statement: Not applicable.

Conflicts of Interest: The authors declare no conflict of interest. 


\section{References}

1. FAOSTAT. 2018. Available online: http://www.fao.org/faostat/en/\#data/QC (accessed on 22 October 2018).

2. Carman, H.; Klonsky, K. Organic almond, kiwifruit and winter pear handlers' views on federal marketing order programs. Renew. Agric. Food Sys. 2004, 19, 176-184. [CrossRef]

3. Commission Regulation (EC) No 889/2008 of 5 September 2008 Laying Down Detailed Rules for the Implementation of Council Regulation (EC) No 834/2007 on Organic Production and Labelling of Organic Products with Regard to Organic Production, Labelling and Control. Available online: http://data.europa.eu/eli/reg/2008/889/oj (accessed on 6 April 2018).

4. Bustamante, M.A.; Paredes, C.; Morales, J.; Mayoral, A.M.; Moral, R. Study of the composting process of winery and distillery wastes using multivariate techniques. Bioresour. Technol. 2009, 100, 4766-4772. [CrossRef] [PubMed]

5. Paradelo, R.; Moldes, A.B.; Barral, M.T. Utilization of a factorial design to study the composting of hydrolyzed grape marc and vinification lees. J. Agric. Food Chem. 2010, 58, 3085-3092. [CrossRef] [PubMed]

6. Bustamante, M.A.; Said-Pullicino, D.; Paredes, C.; Cecilia, J.A.; Moral, R. Influences of winery-distillery waste compost stability and soil type on soil carbon dynamics in amended soils. Waste Manag. 2010, 30, 1966-1975. [CrossRef] [PubMed]

7. Sanchez-Bel, P.; Egea, I.; Martinez-Madrid, M.C.; Flores, B.; Romojaro, F. Influence of irrigation and organic/inorganic fertilization on chemical quality of almond (Prunus amygdalus cv. Guara). J. Agric. Food Chem. 2008, 56, 10056-10062. [CrossRef]

8. Solano, M.L.; Iriarte, F.; Ciria, P.; Negro, M.J. Performance characteristics of three aeration systems in the composting of sheep manure and straw. J. Agric. Eng. Res. 2001, 79, 317-329. [CrossRef]

9. Bustamante, M.A.; Paredes, C.; Marhuenda-Egea, F.C.; Pérez-Espinosa, A.; Bernal, M.P.; Moral, R. Co-composting distillery wastes with animal manure: Carbon and nitrogen transformations and evaluation of compost stability. Chemosphere 2008, 72, 551-557. [CrossRef] [PubMed]

10. Real Decreto 999/2017, de 24 de noviembre, por el que se modifica el Real Decreto 506/2013, de 28 de junio, sobre productos fertilizantes. Boletín Oficial del Estado 2017, 296, 119396-119450. (In Spanish)

11. Bustamante, M.A.; Pérez-Murcia, M.D.; Paredes, C.; Moral, R.; Pérez-Espinosa, A.; Moreno-Caselles, J. Short-term carbon and nitrogen mineralisation in soil amended with winery and distillery organic wastes. Bioresour. Technol. 2007, 98, 3269-3277. [CrossRef] [PubMed]

12. Kitson, R.E.; Mellon, M.G. Colorimetric determination of P as molybdovanadate phosphoric acid. Ind. Eng. Chem. Anal. Ed. 1944, 16, 379-383. [CrossRef]

13. Gallardo-Lara, F.; Nogales, R. Effect of the application of town refuse compost on the soil-plant system: A review. Biol. Wastes 1987, 19, 35-61. [CrossRef]

14. Glover, J.D.; Reganold, J.P.; Andrews, P.K. Systematic method for rating soil quality of conventional, organic, and integrated apple orchards in Washington State. Agric. Ecosyst. Environ. 2000, 80, 29-45. [CrossRef]

15. Sánchez-Monedero, M.A.; Mondini, C.; de Nobili, M.; Leita, L.; Roig, A. Land application of biosolids. Soil response to different stabilization degree of the treated organic matter. Waste Manag. 2004, 24, 325-332. [CrossRef] [PubMed]

16. Valverde, M.; Madrid, R.; García, A.L. Effect of the irrigation regime, type of fertilization, and culture year on the physical properties of almond (cv. Guara). J. Food Eng. 2006, 76, 584-593. [CrossRef]

17. Muhammad, S.; Sanden, B.L.; Saa, S.; Lampinen, B.D.; Smart, D.R.; Shackel, K.A.; DeJong, T.M.; Brown, P.H. Optimization of nitrogen and potassium nutrition to improve yield and yield parameters of irrigated almond (Prunus dulcis (Mill.) D.A. webb). Sci. Hortic. 2018, 228, 204-212. [CrossRef]

18. Gunes, N.T.; Okay, Y.; Koksal, A.I.; Koroglu, M. The effect of nitrogen and phosphorus fertilization on yield, some fruit characteristics, hormone concentrations, and alternate bearing in pistachio. Turk. J. Agric. For. 2010, 34, 33-43. [CrossRef]

19. Neilsen, G.H.; Neilsen, D.; Herbert, L. Nitrogen fertigation concentration and timing of application affect nitrogen nutrition, yield, firmness, and color of apples grown at high density. Hortscience 2009, 44, 1425-1431. [CrossRef]

20. Brown, P.H.; Weinbaum, S.A.; DeJong, T.M. Reassessment of Potassium Critical Values. In Years of Discovery (1972-2003); Almond Board of California: Modesto, CA, USA, 2000.

21. Reidel, J.E.; Brown, P.H.; Duncan, R.A.; Heerema, R.J.; Weinbaum, S.A. Sensitivity of yield determinants to potassium deficiency in 'Nonpareil' almond (Prunus dulcis (Mill.) DA Webb). J. Horticul. Sci. Biotechnol. 2004, 79, 906-910. [CrossRef]

22. Askin, M.A.; Balta, M.F.; Tekintas, F.E.; Kazankaya, A.; Balta, F. Fatty acid composition affected by kernel weight in almond [Prunus dulcis (Mill.) D.A. Webb.] genetic resources. J. Food Compos. Anal. 2007, 20, 7-12. [CrossRef] 